Materials (Data)

|||||||||||||||||||||||||||||||||||||||||||||||||||||||||||||

\title{
The Studies of in Vivo Distributions of Radioiodinated Cobalt-bleomycin in Tumor-bearing Animals by the Whole Body Autoradiography
}

\author{
Atsushi Ando* ${ }^{\dagger}$, Itsuko Ando*, Hirohumi SudA ${ }^{* *}$, Kazuyuki Nishimoto**, Shintaro KameI ${ }^{* *}$, \\ Jun Kosaka***, Yoshihiro NishiYama ${ }^{* * * *}$, Yuka Yamamoto****, \\ Masahiro Kuroda ${ }^{* * * * *}$ and Susumu KanazawA ${ }^{*}$ \\ * Department of Radiology, Okayama University Medical School \\ 2-5-1 Shikata-cho, Okayama Pref. 700-8558, Japan \\ ** Division of Radioisotope Research, Life Science Research Center, Kagawa University \\ 1750-1 Ikenobe, Miki-cho, Kita-gun, Kagawa Pref. 761-0793, Japan \\ *** Departmemt of Anatomy, School of Medicine, International University of Health and Welfare \\ 4-3 Kozunomori, Narita, Chiba Pref. 286-8686, Japan \\ **** Department of Radiology, Faculty of Medicine, Kagawa University \\ 1750-1 Ikenobe, Miki-cho, Kita-gun, Kagawa Pref. 761-0793, Japan \\ ***** Radiological Technology, Graduate School of Health Sciences, Okayama University \\ 2-5-1 Shikata-cho, Okayama Pref. 700-8558, Japan \\ †a-ando@themis.ocn.ne.jp
}

Received August 30, 2016

Accepted March 27, 2017

\begin{abstract}
High tumor uptake of cobalt-bleomycin suggested that it would be a suitable starting material for chemical modification study. We already described the synthesis of 3-125I-iodobenzyl cobalt-bleomycin and its in vivo distributions in tumor-bearing animals. In the present study, it was shown by the whole body autoradiogram that 3- ${ }^{225}$ I-iodobenzyl cobalt-bleomycin accumulated in tumor (dorsum, thigh, neck), the kidney, the liver and feces. Tumor affinity of this compound was proved by the results of the whole body autoradiogram.
\end{abstract}

Key Words: cobalt-bleomycin, iodine-125, scid mouse, malignant tumor, whole body autoradiography

\section{Introduction}

It was reported by Umezawa et al. ${ }^{1)}$ that the bleomycins were a group of antibiotics and their therapeutic effect against carcinoma was proved by clinical studies. ${ }^{57} \mathrm{Co}$-bleomycin which is produced by binding radioactive cobalt (Co-57) to bleomycin accumulates selectively in cancer and the excellent clinical results obtained with this compound. ${ }^{2-7)}$ ${ }^{57} \mathrm{Co}$-bleomycin was introduced for tumor scanning by Nouel et al., ${ }^{4)}$ and by Kono et al. ${ }^{2)}$ and by Maeda et al. ${ }^{3)}$ in 1972, and has been used mainly in Europe and Japan. Suzuki et al. ${ }^{7)}$ described their clinical experience with ${ }^{57} \mathrm{Co}$-bleomycin in various tumors and discussed its clinical significance. Tumor scanning with ${ }^{57} \mathrm{Co}$-bleomycin was carried out in 46 patients with an overall accuracy of $66 \%$ in malignant tumors. There were no genuine false positive results in four benign lesions. Since ${ }^{57} \mathrm{Co}$-bleomycin is excreted rapidly through the kidneys, a high tumorto-blood ratio is obtained a short time after injection. Although its long physical half-life may restrict its routine use, ${ }^{57} \mathrm{Co}$-bleomycin might provide a valuable adjunct in the work-up of malignant tumors 
when used in properly selected patients.

However, the long physical half-life of ${ }^{57} \mathrm{Co}(270$ days) prevented its widespread clinical use.

High tumor uptake of cobalt-bleomycin suggested that it would be a suitable starting material for chemical modification studies.

Our study aimed at labeling cobalt-bleomycin with radioactive iodine and at clarifying its tumorlocalizing property, because this element has several nuclides which are suitable for SPECT $\left({ }^{123} \mathrm{I}\right)$, PET $\left({ }^{124} \mathrm{I}\right)$, radiation therapy $\left({ }^{131} \mathrm{I}\right)$, and basic research $\left({ }^{125} \mathrm{I}\right)$.

We already described the synthesis of 3-125I-iodobenzyl cobalt-bleomycin (3-125I-Bz-Co-BLM) and its in vivo distributions in tumor-bearing animals. ${ }^{8)}$ In this paper, we show the whole body autoradiogram of tumor-bearing mice which were injected with 3-125I-Bz-Co-BLM.

\section{Materials and methods}

\section{2・1 Materials}

Bleomycin $\mathrm{A}_{2}$ sulfate was given by NIPPON KAYAKU Co., LTD. (Japan). We purchased Iodine-125 (as $\mathrm{Na}^{125} \mathrm{I}$ ) from Perkin Elmer life and analytical sciences (USA), 3-iodobenzylalcohol and diphosphorus tetraiodide $\left(\mathrm{P}_{2} \mathrm{I}_{4}\right)$ from Sigma-Aldrich com (USA), cobalt chloride hexahydrate, citric acid monohydrate, 2,5-dihydroxybenzoic acid, copper sulfate pentahydrate and tin chloride dihydrate from Wako Pure Chemical Industries, Ltd (Japan) and male scid mice from Clea Japan, Inc. (Japan). Male scid mice (eight weeks old) were implanted with Ehrlich tumor ( $\mathrm{ca} .4 \times 10^{7}$ cells) in the thigh and the dorsum and used for these experiments six days later.

\subsection{Methods}

3-125I-Bz-Co-BLM: synthesized by the method described by us. ${ }^{8)}$

3- ${ }^{125} \mathrm{I}-\mathrm{Bz}-\mathrm{Co}-\mathrm{BLM}$ was prepared for the injection reagent to mice. This solution $(0.3 \mathrm{~mL})$ contained about $11 \mathrm{kBq}$ and $40 \mu \mathrm{g}$ of $3-{ }^{125} \mathrm{I}-\mathrm{Bz}-\mathrm{Co}-\mathrm{BLM}$.
$3-{ }^{125} \mathrm{I}-\mathrm{Bz}-\mathrm{Co}-\mathrm{BLM}$ injection reagent $(0.3 \mathrm{~mL})$ was administered intraveneously through the tail vein of the above tumor-bearing mice, respectively. These mice ( $n=3$, weight $23.5-25.7 \mathrm{~g}$ ) were sacrificed under carbon dioxide from dryice at three hours after the administration.

Sacrificed mice were frozen rapidly in acetone cooled to $-70^{\circ} \mathrm{C}$ with dryice. The frozen mice were embedded in a gel of carboxymethyl cellulose sodium salt, and these mounted mice were frozen again in a similar manner. Sagittal sections $(40 \mu \mathrm{m})$ through the whole frozen mice were taken from the tissues of interest with a cryomicrotone (Autocryotome NA-500F Nakagawa seisakusho) at $-20^{\circ} \mathrm{C}$. These frozen sections were dried at $-20^{\circ} \mathrm{C}$, and then exposed to an imaging plate (FUJIFILM FLA-700) for four weeks.

\section{Results and discussion}

In three mice administered with $3-{ }^{125} \mathrm{I}-\mathrm{Bz}-\mathrm{Co}-$ BLM, very similar results were obtained. Fig. 1 illustrates the results of a typical mouse.

Fig. 1(A) shows the sagittal section of a mouse administered with $3-{ }^{125} \mathrm{I}-\mathrm{Bz}-\mathrm{Co}-\mathrm{BLM}$, and tumor, liver, kidney, lung and feces are shown in this Figure by arrows.

Fig. 1(B) shows the whole body autoradiogram of this sagittal section. This indicates that radioactivities accumulate in the tumor (dorsum, thigh), the kidney, the liver and feces. In the tumor tissue, the accumulation of radioactivity in the viable tumor tissue was much more than in the necrotic tumor tissue.

In the Fig. 1(A), unexpectedly, it was found that small tumors (indicated by four small arrows) grew in the neck after the transposition of some tumor cells from the dorsum.

As shown in Fig. 1(B), radioactivities (indicated by four small arrows) accumulated in these small tumors.

Of ${ }^{57}$ Co-bleomycin, Kono et al. ${ }^{5,6)}$ described that ${ }^{57} \mathrm{Co}$-bleomycin accumulated in the tumor tissue and 

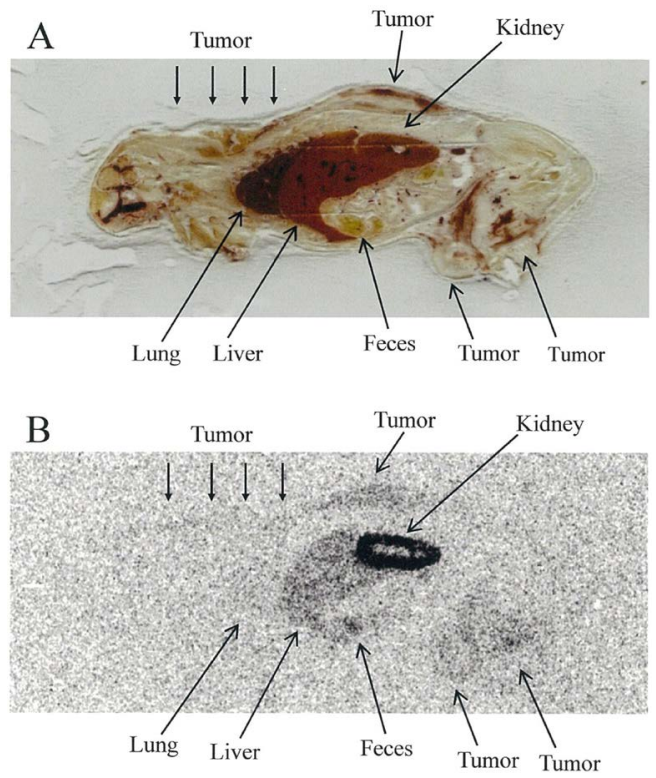

Fig. 1 Illustrates the results of a typical mouse. (A) shows the sagittal section of a mouse administered with $3-{ }^{125} \mathrm{I}-\mathrm{Bz}-\mathrm{Co}-\mathrm{BLM}$. (B) shows the whole body autoradiogram of this sagittal section. This indicates that radioactivities accumulated in tumor (dorsum, thigh, neck), the kidney, the liver and feces (Color online).

this compound located only in the viable tumor tissue and was not seen in the necrotic tumor tissue, and that ${ }^{57} \mathrm{Co}$-bleomycin bound to DNA in tumor cell.

From the results by Kono et al.,5, 6) by us ${ }^{8)}$ and the present study, we presume that $3-{ }^{125} \mathrm{I}-\mathrm{Bz}-\mathrm{Co}-\mathrm{BLM}$ accumulates in the viable tumor tissue and binds to DNA in tumor cell.

We already reported that the accumulation of 3-125I-Bz-Co-BLM in tumor tissue was much more than other normal organs except the kidney and the liver. ${ }^{8)}$ The present study illustrates the results described above. This fact that this compound had considerably strong affinity for malignant tumor was proved by the whole body autoradiography. Unexpectedly, small tumors which grew in the neck after the transposition from the dorsum were confirmed by the whole body autoradiography.

We are planning to observe the distribution of
3- ${ }^{125} \mathrm{I}-\mathrm{Bz}-\mathrm{Co}-\mathrm{BLM}$ in the tumor tissue by microautoradiography and to scan tumor-bearing animals after intravenous injection of 3-125I-Bz-Co-BLM.

\section{Conclusion}

It was shown by the whole body autoradiogram that radioactivities accumulated in the tumor (dorsum, thigh, neck), the kidney, the liver and feces. Tumor affinity of 3- ${ }^{-125} \mathrm{I}$-Bz-Co-BLM was proved by the whole body autoradiogram.

\section{Acknowledgments}

The authors appreciate sincerely NIPPON KAYAKU Co., LTD. (Japan) which gave bleomycin $\mathrm{A}_{2}$ sulfate to us.

\section{References}

1) Umezawa, H., Natural and artificial bleomycins: Chemistry and antitumour activities, Pure Appl. Chem., 28, 665-680 (1971)

2) Kono, A., Kojima, M. and Maeda, T., The Tumor specific localizing agents for radioisotope image: The preparation of labeled bleomycin and their distributions in the tumor bearing mice, RADIOISOTOPES, 21, 118-120 (1972)

3) Maeda, T., Kono, A. and Kojima, M., Tumor scanning with ${ }^{57}$ Co-bleomycin, RADIOISOTOPES, 21, 436-438 (1972)

4) Nouel, J. P., Renault, H., Robert, J., Jeanne, C. and Wicart, L., La bleomycine marquee au Co 57, Nouv. Presse Med., 8, 95-98 (1972)

5) Kono, A., Matsushima, Y., Kojima, M. and Maeda, T., Cobalt chelate of bleomycin. I. Physicochemical properties and distribution in tumor bearing mice, Chem. Pharm. Bull. (Tokyo), 25, 1725-1731 (1977)

6) Kono, A., Cobalt chelate of bleomycin. II. Binding to deoxyribonucleic acid of Ehrlich solid tumor in mice, Chem. Pharm. Bull. (Tokyo), 25, 2882-2886 (1977)

7) Suzuki, Y., Hisada, K., Hiraki, T. and Ando, A., Clinical evaluation of tumor scanning with ${ }^{57} \mathrm{Co}$ bleomycin, Radiology, 113, 139-143 (1974)

8) Ando, A., Ando, I., Kuroda, M., Kanazawa, S. and Hiraki, Y., The synthesis of radioiodinated Cobaltbleomycin and its in vivo distributions in Tumorbearing animals, RADIOISOTOPES, 60, 1-8 (2011) 


\section{和文要旨}

\section{全身オートラジオグラフィによる放射性ヨウ素標識 コバルト-ブレオマイシンの担がん動物における体内}

\section{分布の研究}

安東 醇 ${ }^{* \dagger}$, 安東逸子*, 須田博文**, 西本一幸**, 亀井信太郎**, 小阪 淳***, 西山佳宏****, 山本 由佳 $* * *$, 黑田昌宏*****, 金澤 右*: *岡山大学 医学部放射線医学教室, 700-8558 岡山県岡山市北 区鹿田町 2-5-1, **香川大学総合生命科学研究セン ター放射性同位元素実験部門（医学部地区），7610793 香川県木田郡三木町池戸1750-1, $* * *$ 国際医 療福祉大学医学部解剖学, 286-8686 千葉県成田市 公津の杜 4-3, ****香川大学医学部放射線医学教室,
761-0793 香川県木田郡三木町池戸 1750-1， ******岡 山大学大学院保健学研究科, 700-8558 岡山県岡山 市北区鹿田町 2-5-1, ${ }^{\dagger}$ a-ando@themis.ocn.ne.jp コバルトーブレオマイシンは腫瘍に多く取り込まれ るので, この化合物は化学的に修飾するための出発 物質に適している。我々は既に， 3- ${ }^{125} \mathrm{I}-$ コバルトーブ レオマイシンの合成とこの化合物の担がん動物にお ける体内分布を報告した。今回の研究で, $3-{ }^{125} \mathrm{I}$-コ バルトーブレオマイシンが腫瘍（背，大腿皮下，首）, 腎臓，肝臓，凟に多く集積することが全身オートラ ジオグラムによって示された。この化合物の腫瘍親 和性が全身オートラジオグラムによって証明された。 2016年8月30日 受付 2017年3月27日 受理 